Miedo al COVID-19 y agotamiento de la Enseñanza online en los Maestros Filipinos (Infantil - 12 años).

\title{
Fear of COVID-19 and Remote Teaching Burnout of Philippine K to 12 Teachers
}

\author{
Thalia Carreon. \\ Balite Elementary School, General Santos City, Philippines. \\ thaliarcarreon25@gmail.com \\ Erwin Rotas. \\ Department of Education, General Santos City, Philippines. \\ erwinemperadorotas@gmail.com \\ Michael Cahapay. \\ College of Education, Mindanao State University, \\ General Santos City, Philippines. \\ mbcahapay@up.edu.ph \\ Kenneth Garcia. \\ Romana C. Acharon Central Elementary School, \\ General Santos City, Philippines. \\ garciakenneth1.0@gmail.com \\ Romina Amador. \\ Severo T. Inong Elementary School, Philippines. \\ rominamamador@gmail.com \\ Jeorge Louie Anoba. \\ Carpenter Hill Elementary School, Koronadal City, Philippines. \\ Jeorge.anoba@deped.gov.ph
}

\section{Resumen.}

La crisis de COVID-19 prácticamente magnificó el miedo normal de las personas, trayendo más resultados psicológicos negativos como el agotamiento laboral. Partiendo de esta suposición, este documento tuvo como objetivo comparar el miedo al COVID-19 y el agotamiento de la enseñanza remota a través de las características de la muestra y relacionar el miedo al COVID-19 con el agotamiento de la enseñanza remota. Siguiendo diseños de investigación comparativos y correlacionales, se seleccionó una muestra de 1069 profesores filipinos (infantil- 12 años) para participar en la encuesta en línea. Los datos se analizaron mediante estadística descriptiva e inferencial. Los resultados mostraron que los docentes tienen un alto nivel de miedo al COVID-19 y un nivel moderado de agotamiento de la enseñanza a distancia. Además, el miedo de COVID-19 a los maestros no difirió significativamente en todas las características de la muestra evaluadas; sin embargo, el agotamiento de la enseñanza a distancia difirió significativamente según la edad, los ingresos mensuales, el nivel educativo y la experiencia docente, excepto el género. Además, se reveló que existe una relación significativa positiva y moderada entre el miedo al COVID-19 y el agotamiento de la enseñanza a distancia. Esta asociación lineal implica que a medida que aumenta el miedo al COVID-19 de los docentes, también aumenta el desgaste de la enseñanza a distancia. Considerando la actual persistencia de los casos de COVID-19 y el

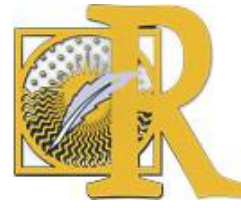

Fecha de recepción: 23-03-2021 Fecha de aceptación: 11-04-2021

Carreon, T., Rotas, E., Cahapay,M., Garcia,K., Amador, R. \& Anoba, J.L. Miedo al COVID-19 y al agotamiento de la Enseñanza Remota de los Maestros Filipinos de K a 12. 
papel de los docentes en la fase de recuperación anticipada de la educación, los resultados del estudio indican la atención urgente de las autoridades educativas para desarrollar medidas para atender las necesidades de los docentes que puedan tener problemas psicológicos planteados por miedo al COVID-19 y al agotamiento de la enseñanza a distancia.

\section{PALABRAS CLAVE.}

Efectos psicológicos, educación a distancia, profesores, pandemia, Filipinas.

\section{ABSTRACT.}

The COVID-19 crisis practically magnified the normal fear of people, bringing further negative psychological outcomes such as job burnout. Building on this assumption, this paper aimed to compare fear of COVID-19 and remote teaching burnout across sample characteristics and relate fear of COVID-19 to the remote teaching burnout. Following comparative and correlational research designs, a sample of $1069 \mathrm{~K}$ to 12 teachers from Mindanao, Philippines was selected to participate in the online survey. The data were analyzed using descriptive and inferential statistics. The results showed that the teachers have a high level of fear of COVID19 and a moderate level of remote teaching burnout. Furthermore, COVID-19 fear of teachers did not significantly differ across all sample characteristics tested; however, remote teaching burnout significantly differed across age, monthly income, educational attainment, and teaching experience, except gender. It was further revealed that there is a positive and moderate significant relationship between fear of COVID-19 and remote teaching burnout. This linear association implies that as fear of COVID-19 of teachers increases, their remote teaching burnout also increases. Considering the current persistence of COVID-19 cases and the role of teachers in the anticipated recovery phase of education, the results of the study indicate the urgent attention of education authorities to develop measures to address the needs of teachers who may have psychological issues brought by fear of COVID-19 and remote teaching burnout.

\section{KEY WORDS.}

Psychological effect, distance education, teachers, pandemic, Philippines.

\section{Introduction.}

The difficult situation brought by the COVID-19 has affected almost every sector of society, including the sector of education. Amid the stringent measures, educational systems struggle to provide quality education. As the crisis continues to persist for more than a year now, it has also been that long since schools operate differently from their conventional ways. Fraught with many difficulties, teachers have to adapt to new ways of education. One of the psychological outcomes of this experience is the fear (Hidalgo et al., 2020).

Delamater and Ewart (2020) affirm that the COVID-19 crisis has magnified the normal fear level of teachers as the situation brought tremendous adjustments and challenges. Among those magnified fears of teachers is the pressure to adjust and comply with certain standards in a new normal set-up such as the use of educational technology (Fernandez-Batanero, et al., 2020). Broadly speaking, fear is an emotion that gives a proportionate reaction to a

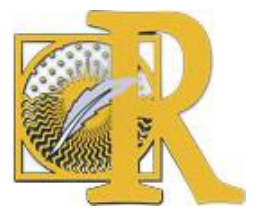


foreseen threat or dangerous situation (Moehle \& Levitt, 1991). It is an adaptive behavior in the existence of danger and threat (Mertens et al., 2020). Moreover, people may learn to fear if they experience pain or stress (Steimer, 2002). Within the context of education, the COVID19 crisis has raised various types of fears in the teachers (Salloum et al., 2020).

Researchers and authorities, like World Health Organization, American Psychiatric Association, Philippine Mental Health Association, have acknowledged the influence of fear of COVID-19 on several aspects of teaching conditions including efficacy, motivation, satisfaction, stress (Aperribai, 2020), and burnout (Huo et al., 2020), the last is which the interest of this study. Conceptually, burnout can be defined as a psychological condition caused by excessive and prolonged stress (Maslach \& Leiter, 2016). Within different contexts of human affairs, the association between fear and burnout have been confirmed in the past by some scholarly works (e.g. Demerouti et al., 2002; Motaghi-Pishe, 2008; Hanson et al., 2015; Gustafsson, 2016; Fried \& Fisher, 2017; Portoghese et al., 2017; Gezgin, et al., 2017; Mahmoodi-Shahrebabaki, 2019; and Arvidsson, et al., 2019.

A synthesis of current related studies concludes that there is a significant relationship between fear and burnout in the context of the COVID-19 crisis (e.g. Hu, 2020 on frontliners; Abdelghani, 2020 on physicians; Guisti, 2020 on health professionals; Prikhido \& Wheaton, 2020 on parents; Gonzalez-Hernandez, et al., 2021 on teen handball players; and Son et al., 2020 on college students). However, in the absence of empirical evidence regarding the fear of COVID-19 and its influence on remote teaching burnout, there is a notable gap in this research interest in the context of education.

With the continuing COVID-19 crisis and the role of teachers as primary workers in the continuity of education for the learners, this paper stresses the significance of assessing the psychological condition of the teachers. An investigation of the relationship between fear of COVID-19 and burnout of teachers can provide a basis for analyzing the needs of teachers and provide a proper measure. This paper hopes to open windows of opportunities for relevant actions that may improve the psychological conditions of teachers, thus enhancing the quality of delivery of instruction to the learners.

Thus, the purpose of this paper is twofold: 1.) to compare fear of COVID-19 and remote teaching burnout across sample characteristics and 2.) to relate fear of COVID-19 to the remote teaching burnout.

\section{Theoretical Framework.}

This study is grounded on a combination of theories. Many scholarly works using fear and burnout as constructs of research interest typically point to the notion of Lazarus and Folkman (1984) on psychological stress and coping theory as a basis. This theory specifically posits that fear is evidence of a particular stress appraisal. It could be viewed as a stress emotion because of its connection to harmful situations. The association between fear and burnout, however, is not strongly and directly established in this theory. It was the framework of Rogers and Kelloway (1997) that made expansions of this traditional work stress framework. Particularly, in this new framework, it was posited that fear has negative psychological, occupational, and physiological outcomes (Barling, 1996), of which one may be burnout (Gross et al., 2013). Several studies in the past and present (e.g. see Demerouti et al., 2002;

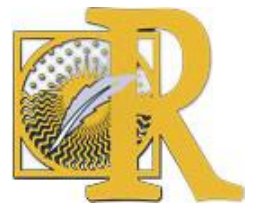

Fecha de recepción: 23-03-2021 Fecha de aceptación: 11-04-2021

Carreon, T., Rotas, E., Cahapay,M., Garcia,K., Amador, R. \& Anoba, J.L. Miedo al COVID-19 y al agotamiento

de la Enseñanza Remota de los Maestros Filipinos de K a 12.

International Journal of Educational Research and Innovation (IJERI), 15, 552-567

ISSN: 2386-4303 DOI https://doi.org/10.46661/ijeri.5853 
Hanson et al., 2015; Abdelghani, 2020; Hu, 2020; Son et al., 2020) have recognized the association between fear and burnout in different contexts. The current paper is an extension of these studies, but this time, in the complex context of education amid the COVID-19 crisis.

\section{Methods.}

This section outlines the method for determining the correlation between fear of COVID-19 and remote teaching burnout of $\mathrm{K}$ to 12 teachers. They are elaborated as follows.

\section{Research Design.}

This study is a quantitative type of research. Specifically, it applied a correlational design. Curtis (2016) defined a correlational research design as the measurement of two or more factors to identify the degree to which these factors are related or change in an identifiable pattern. This design is suited for this study as it attempted to test the respective association between the sample characteristics and fear of COVID-19 to the remote teaching burnout.

\section{Sampling.}

The respondents of this study were 1,069 Filipino K to 12 teachers in Mindanao, Philippines. They were selected through a combination of purposive and snowball sampling techniques in which researchers started with a small number of known teachers, mostly teaching in the same or nearby areas and are personally known to them. The sampling was expanded by asking these teachers to identify other potential respondents until the present sample size was established (Crossman, 2020). The respondents were chosen regardless of gender, age, religion, position, educational attainment, and socioeconomic status.

\section{Instruments.}

This research used two instruments to gather the needed data. The first instrument was completely adapted from the Fear of COVID-19 Scale originally developed by Ahorsu et. al (2020). It has seven items intended to assess the level of fear of COVID-19 in a five-point Likert scale ranging from 1 as Strongly disagree and 5 as strongly agree. It generated a very good reliability score $(\alpha=0.905)$ when evaluated in the Filipino sample. This means that it has a good internal consistency. The second instrument was a modified online teaching burnout tool from the study of Panisoara et. al (2020). Specifically, the items were changed to the context of remote teaching to be more relevant to the context of this study. It has four items also answerable in a five-point Likert scale ranging from 1 as Strongly disagree and 5 as strongly agree. The current reliability of this instrument is also very good $(\alpha=0.904)$, affirming a good internal consistency.

\section{Data Collection.}

The data collection for this study was conducted from January 25 to February 05, 2021, via an online survey through a Google link. The survey came in two parts. The first part involved the introduction to the study and gaining consent from the target participants. The researchers explained the purpose of the study and the voluntary role of the respondents in providing the

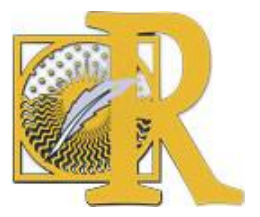

Fecha de recepción: 23-03-2021 Fecha de aceptación: 11-04-2021 
needed data. They were assured that the confidentiality of the information will be maintained throughout the process.

The second part consisted of the main questionnaire. It initially asked for the personal information of the respondents such as age, gender, rank, civil status, monthly income, educational attainment, school type, teaching level, and teaching experience. Then, it presented the seven-item Fear of COVID-19 Scale. It then presented the four-item scale on remote teaching burnout. After accessing and answering, their responses were automatically recorded. Finally, the researchers generated the data.

\section{Data Analysis.}

The gathered data were initially analyzed using descriptive statistics. Mean and standard deviation were used to determine the levels of fear of COVID-19 of the teachers and burnout caused by remote teaching. On the other hand, frequency count and percentage rate were employed to describe the sample characteristics.

The data of this study met the assumption of normality. Thus, to assess whether there is a significant difference in the fear of COVID-19 and remote teaching burnout across sample characteristics, inferential statistics were used. For sample characteristics such as gender, monthly income, marital status, educational attainment, and teaching rank with two levels, the $t$ test for independent samples was used. For sample characteristics such as age and teaching experience with three or more levels, ANOVA and Tukey Test were utilized. Furthermore, to examine the correlation between the two variables in this study, Pearson Product Moment Correlation Coefficient was employed. The correlation coefficient is used to measure the strength and direction of the correlation between the two factors mentioned above. Its value can range from -1.0 to +1.0 (Curtis, 2016).

All tests were done at 0.05 level of significance. Computations were performed using Statistical Package for Social Sciences (SPSS) version 16.

\section{Result and Discussion.}

This paper primarily aimed to determine the correlation between fear of COVID-19 and remote teaching burnout. This section presents the result and discussion as follows. 


\section{Sample Characteristics.}

Table 1. Sample Characteristics

\begin{tabular}{|l|l|c|c|}
\hline \multicolumn{2}{|c|}{ Sample Characteristics } & $\mathbf{n}$ & \% \\
\hline \multirow{4}{*}{ Age } & 34 years old and below & 594 & 55.6 \\
\cline { 2 - 4 } & 35 to 44 years old & 266 & 24.9 \\
\cline { 2 - 4 } & 45 years old and above & 209 & 19.6 \\
\hline \multirow{2}{*}{ Gender } & Male & 216 & 20.2 \\
\cline { 2 - 4 } & Female & 853 & 79.8 \\
\hline \multirow{3}{*}{ Educational Attainment } & PHP23,000 and below & 674 & 63.0 \\
\cline { 2 - 4 } & PHP24,000 and above & 395 & 37.0 \\
\hline \multirow{3}{*}{ Teaching Experience } & Undergraduate degree & 602 & 56.3 \\
\cline { 2 - 4 } & Graduate units or degree & 467 & 43.7 \\
& $0-10$ years & 792 & 74.1 \\
\cline { 2 - 4 } & $11-20$ years & 172 & 16.1 \\
\cline { 2 - 4 } & 21 years and above & 105 & 9.8 \\
\hline
\end{tabular}

Table 2 shows the characteristics of the sample. The results indicate that more than half of the respondents belong to the age bracket of 34 years old and below $(n=594 ; 55.6 \%)$ while the remaining to $35-44$ years old $(n=266 ; 24.9 \%)$ and 45 years old and above $(n=209 ; 19.6 \%)$. As per gender, there were more female respondents $(n=853 ; 79.79 \%)$ than male respondents $(n=216 ; 20.21 \%)$. When it comes to monthly income, most teachers earn PHP23,000 below $(n=674 ; 63 \%)$ and the rest earn PHP24,000 above ( $n=395 ; 37 \%)$. It is further shown that the majority of them have at least an undergraduate degree $(n=602 ; 56.3 \%)$ and a considerable number have graduate units or degree $(n=467 ; 43.7 \%)$. Lastly, a large majority of the teachers have teaching experience of $0-10$ years $(n=792 ; 74.1 \%)$ and others have been in the teaching job for $11-20$ years $(n=172 ; 16.1 \%)$ and 21 years and above $(n=105 ; 9.8 \%)$.

\section{Fear of COVID-19.}

Table 2. Fear of COVID-19.

\begin{tabular}{|l|l|l|l|}
\hline \multicolumn{1}{|c|}{ Item } & \multicolumn{1}{c|}{ Mean } & \multicolumn{1}{c|}{ SD } & \multicolumn{1}{c|}{ Rank } \\
\hline 1. I am most afraid of Corona. & 4.23 & 1.00 & 2 \\
\hline 2. It makes me uncomfortable to think about Corona. & 4.05 & 1.03 & 3 \\
\hline 3. My hands become clammy when I think about Corona. & 3.22 & 1.26 & 5 \\
\hline $\begin{array}{l}\text { 4. I am afraid of losing my life because of Corona. } \\
\text { 5. When I watch news and stories about Corona on social } \\
\text { media, I become nervous or anxious. }\end{array}$ & 3.49 & 1.11 & 1 \\
\hline $\begin{array}{l}\text { 6. I cannot sleep because I'm worrying about getting Corona. } \\
\text { 7. My heart races or palpitates when I think about getting }\end{array}$ & 2.66 & 1.17 & 4 \\
\hline Corona. & 2.83 & 1.32 & 7 \\
\hline
\end{tabular}

$$
\mathrm{n}=1069
$$


Table 2 displays the level of fear of COVID-19 of teachers in each item. The result disclosed that the teachers strongly agree that they are afraid of losing their lives because of Corona $(M=4.24 ; S D=1.11)$ and that they are most afraid of corona $(M=4.23 ; S D=1.00)$. Moreover, they agree that it makes them uncomfortable to think about corona $(M=4.05 ; S D=1.03)$, and when they watch news and stories about it, they become nervous and anxious ( $M=3.49$; $\mathrm{SD}=1.17$ ). It indicates that, based on these top items, teachers generally demonstrate a high level of fear towards COVID-19.

The result shows that these statements generated the highest means among the indicators showing that teachers experience high levels of fear. The fear of COVID-19 was also explored on different samples using the same scale, showing the same high level of fear on the mentioned indicators (e.g. Soraci et al. 2020 on Italians; Ahorsu et al., 2020 on Iranians; Doshi et al., 2020 on Indians). Interestingly, the trend on this result suggests that these indicators are related to psychological facets of fear presenting constructs of afraid, uncomfortable, nervous, and anxiety (Barrios et al., 2020).

On the other hand, teachers are neutral as regards their hands becoming clammy when they think of corona $(M=3.22 ; S D=1.26)$, heart races or palpitates when they think about getting Corona $(\mathrm{M}=2.83$; $\mathrm{SD}=1.32)$, and cannot sleep because they worry about getting Corona $(M=2.66 ; S D=1.29)$. It can be noted that, from these items that got the least scores, teachers experience a moderate level of COVID-19 fear in general.

These statements obtained the lowest means among the indicators presenting moderate levels of fear. This trend is observable in the results of related studies using the same scale on different groups (Sakib et al. 2020 in Bangladeshi; Alyami et al. 2020 in Arabic; Satici et al. 2020 in Turkish). It can be further observed that the items point to the physiological aspect of fear displayed by reactions such as difficulties in sleeping, increased heart palpitation, and feeling of discomfort (Barrios et al. 2020).

Lastly, it obtained an overall mean of 3.54. Based on the arbitrary range values designed in this study, it is described as a high level of fear of COVID-19. This means that teachers generally experience a high level of emotion induced by the perceived danger of COVID-19. This overall result is comparable to various undertakings of other researchers showing teachers experience certain levels of COVID-19 fear described as high (Wu et al. 2020, Delamarter \& Warter, 2020) and moderate (Cervantes-Guevara et al. 2020).

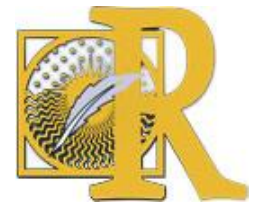

Fecha de recepción: 23-03-2021 Fecha de aceptación: 11-04-2021 


\section{Remote Teaching Burnout.}

Table 3. Remote Teaching Burnout

\begin{tabular}{|l|l|l|l|}
\hline \multicolumn{1}{|c|}{ Item } & \multicolumn{1}{|c|}{ Mean } & \multicolumn{1}{|c|}{ SD } & Rank \\
\hline I feel exhausted from my remote teaching tasks. & 3.08 & 1.12 & 1 \\
\hline $\begin{array}{l}\text { There are days when I feel tired before I start my remote } \\
\text { teaching tasks. }\end{array}$ & 3.01 & 1.14 & 3 \\
\hline $\begin{array}{l}\text { It happens more and more often to negatively talk about my } \\
\text { remote teaching tasks. }\end{array}$ & 2.73 & 1.15 & 4 \\
\hline $\begin{array}{l}\text { I need more time than in the past to relax and feel better after } \\
\text { my remote teaching tasks }\end{array}$ & 3.17 & 1.11 & 2 \\
\hline
\end{tabular}

$\mathrm{n}=1069$

Table 3 shows the level of remote teaching burnout of teachers. The results revealed that teachers are neutral that they need more time than in the past to relax and feel better after their remote teaching tasks $(M=3.17 ; S D=1.11)$, they feel exhausted from their remote teaching tasks $(M=3.08 ; S D=1.12)$, there are days when they feel tired before starting their remote teaching tasks $(M=3.01 ; S D=1.14)$, and it happens more and more often to negatively talk about their remote teaching tasks $(M=2.73 ; S D=1.15)$. As a whole, the remote teaching burnout of the teachers generated an overall mean of 3.00 described as neutral. This implies that teachers experience a moderate level of prolonged job stress caused by remote teaching. Recent studies related to the COVID-19 crisis have shown high levels of burnout among health professionals (e.g. Barello et al., 2020; Hu et al., 2020; Serrão et al., 2020). This is understandable because they currently serve in the overwhelming COVID-19 treatment and care, thus the high level of burnout. However, in the context of education, the result in our sample is the same as that of Sokal (2020) in which teachers generally experience moderate burnout levels. With this result, it can be argued that, while teaching work is heavy for teachers, they can still manage the demands of remote teaching tasks, thus the moderate level of burnout. Nonetheless, this result should not be undermined and proper measures should be given to the teachers. 


\section{Difference in the Fear of COVID-19 and Remote Teaching Burnout.}

Table 4. Difference in the Fear of COVID-19 and Remote Teaching Burnout.

\begin{tabular}{|c|c|c|c|c|c|c|}
\hline \multirow[t]{2}{*}{ Sample Characteristics } & \multicolumn{3}{|c|}{ Fear of COVID-19 } & \multicolumn{3}{|c|}{ Remote Teaching Burnout } \\
\hline & M & $F / t$ & $p$ value & M & $F / t$ & $p$ value \\
\hline Age & & \multirow{4}{*}{1.010} & \multirow{4}{*}{.365} & & \multirow{4}{*}{7.884} & \multirow{4}{*}{.000} \\
\hline 34 years old and below & 3.51 & & & 2.95 & & \\
\hline 35 to 44 years old & 3.55 & & & 2.91 & & \\
\hline 45 years old and above & 3.53 & & & 3.24 & & \\
\hline \multicolumn{2}{|l|}{ Gender } & \multirow{3}{*}{.632} & \multirow{3}{*}{.632} & & \multirow{3}{*}{-1.045} & \multirow{3}{*}{.297} \\
\hline Male & 3.50 & & & 2.98 & & \\
\hline Female & 3.54 & & & 3.06 & & \\
\hline \multicolumn{2}{|l|}{ Monthly Income } & \multirow{3}{*}{-1.395} & \multirow{3}{*}{.163} & & \multirow{3}{*}{-3.093} & \multirow{3}{*}{.002} \\
\hline PHP23,000 and below & 3.50 & & & 2.92 & & \\
\hline PHP24,000 and above & 3.60 & & & 3.12 & & \\
\hline \multicolumn{2}{|l|}{ Educational Attainment } & \multirow{3}{*}{.727} & \multirow{3}{*}{.467} & & \multirow{3}{*}{-2.996} & \multirow{3}{*}{.004} \\
\hline Undergraduate degree & 3.55 & & & 2.92 & & \\
\hline Graduate units or degree & 3.51 & & & 3.09 & & \\
\hline \multicolumn{2}{|l|}{ Teaching Experience } & \multirow{4}{*}{2.350} & \multirow{4}{*}{.096} & & \multirow{4}{*}{7.764} & \multirow{4}{*}{.000} \\
\hline $0-10$ years & 3.55 & & & 2.93 & & \\
\hline $11-20$ years & 3.51 & & & 3.09 & & \\
\hline 21 years and above & 3.58 & & & 3.31 & & \\
\hline
\end{tabular}

Table 4 shows the difference in the fear of COVID-19 and remote teaching burnout of teachers across different sample characteristics. In terms of COVID-19 fear, teachers did not statistically differ based on age ( $F=1.010 ; p=.365)$, gender $(t=.632 ; p=.632)$, monthly income $(t=-1.395 ; p=.163)$, educational attainment $(t=.727 ; p=.467)$, and teaching experience $(F=2.350 ; p=.096)$. Relative to remote teaching burnout, however, teachers statistically differ according to age (34 years old and below $=2.95,35$ to 44 years old $=2.91,45$ years old and above=3.24; $F=7.884 ; p=.000$ ), monthly income (PHP23,000 and below=2.92, PHP24,000 and above $=3.12 ; t=-3.093 ; p=.002$ ), educational attainment (undergraduate degree $=2.92$, graduate units or degree $=3.09 ; t=-2.996 ; p=.004)$, and teaching experience $(0-10$ years $=2.93$, $11-20$ years $=3.09,21$ years-above $=3.31 ; F=7.764 ; p=.000)$, except gender $(t=-1.045 ; p=.297)$. The significant differences in age were specifically observed between the groups of 34 years old-below and 45 years old-above $(p=.001)$ and between $35-44$ years old and 45 years oldabove $(p=.001)$. On the teaching experience, the significant difference was noted between the groups of $0-10$ years and 21 years-above $(p=.001)$. Overall, the result indicates that there are no significant differences in COVID-19 fear and there are significant differences in remote teaching burnout of teachers across age, monthly income, educational attainment, and teaching experience.

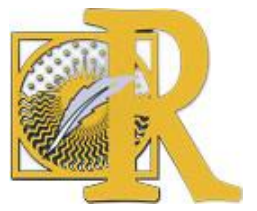

Fecha de recepción: 23-03-2021 Fecha de aceptación: 11-04-2021 
The results of this study are similar to the results of the research conducted by CervantesGuevara et al. (2020) on Mexican teachers, showing no significant difference on the fear of COVID-19 between age $(t=1.91, p>0.05)$. They are also comparable to the results of recent studies on COVID-19 fear conducted in different samples. For instance, no substantial difference in the COVID-19 fear was found among the general Iranian population in terms of age and gender (Ahurso et al. 2020), among the general Italian population in terms of age (Soraci et al. 2020), and among the general Turkish population in terms of educational level $(F=2.40 ; p=0.49)$ and age interval $(F=0.38 ; p=0.82)$ (Haktanir et al. 2020). However, the same authors also found significant statistical difference in the COVID-19 fear across the tested sample characteristics (Cervantes-Guevara et al. (2020) on gender groups of male and female teachers $(t=4.07 ; p=001)$; Haktanir et al. $(2020)$ on gender $(t=4.49 ; p=0.000)$ and socioeconomic levels $(F=3.83 ; p=0.02)$. Similarly, Fitzpatrick et al. (2020) also presented that the COVID-19 fear among the American population is unequally distributed. A higher concentration of COVID-19 fear was noted from groups of females, unemployed, and persons located in regions with greater numbers of confirmed COVID-19 cases.

In terms of remote teaching burnout, similar studies using related variables generated comparable results. The results of the study of Kraft et al. (2020) presented that teachers with varied length of experiences express the same concerns of difficulties in terms of caretaking responsibilities causing burnout. On the other hand, these results negate the study conducted by Zhang et al. (2014) in the context of Chinese teachers showing that no significant differences exist between teaching burnout and age groups ( $p>0.01)$, educational levels $(p>0.01)$, professional titles $(p>0.01)$, or seniority $(p>0.01)$. The same study also claimed that female teachers specifically experience severe intellectual burnout compared to male teachers $(p<0.01)$. Thus, a significant difference between teaching burnout and gender exists. The same results were found in the study of Hayes et al. (2020) on the sample of employees working from home revealing that gender difference was statistically significant $(t=2.59, p=.01)$ but not the length of time spent for work $(t=0.20 ; p=.84)$.

\section{Relationship between Fear of COVID-19 and Remote Teaching Burnout.}

Table 5. Relationship between Fear of COVID-19 and Remote Teaching Burnout

\begin{tabular}{|l|l|}
\hline Variables & Remote Teaching Burnout \\
\hline Fear of COVID-19 & $r=.443 ; p=.000$ \\
\hline
\end{tabular}

Table 5 presents the correlation result between the two variables. It shows that there is a positive and moderate significant relationship between fear of COVID-19 and remote teaching burnout of teachers $(r=.443 ; p=.000)$. The $r$-value further indicates that only about $20 \%$ of the remote teaching burnout of teachers is explained by fear of COVID-19. Nevertheless, this paper provides evidence on the influence of fear of COVID-19 on remote teaching burnout.

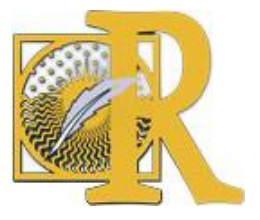

Fecha de recepción: 23-03-2021 Fecha de aceptación: 11-04-2021 
This finding complements the results of related studies using the same variables among frontliners (Hu, 2020), parents (Wheaton, 2020), college students (Son et al., 2020), and health professionals (Giusti, 2020). The trend of the results indicates that fear is a significant factor that affects burnout. Furthermore, the moderate influence of fear of COVID-19 on remote teaching burnout as found in this study suggests that there are other factors that are associated with remote teaching burnout. Fisher (2011) pointed out that burnout may be a result of such other factors as poor working conditions, low student interest, weak administrative support, and excessive number of tasks.

\section{Conclusion.}

Anchored on the notion of an association between two closely linked psychological constructs, this sought to test if fear of COVID-19 is significantly correlated to the remote teaching burnout of Filipino teachers. The central results of this study revealed that the teachers demonstrate a high level of fear of COVID-19 and a moderate level of remote teaching burnout. Furthermore, it can be noted that fear of COVID-19 did not significantly differ across all sample characteristics tested. On the other hand, remote teaching burnout significantly differed across age, monthly income, educational attainment, and teaching experience. Finally, the correlation analysis uncovered a positive and moderate significant relationship between fear of COVID19 and remote teaching burnout. Consistent with the previous studies testing these two variables in different samples such as parents, students, and workers, the results of this study confirms that as the COVID-19 fear increases, burnout also increases. This study specifically proves that, in the context of education, fear of COVID-19 is a significant factor that influences the remote teaching burnout of teachers.

Considering the continued rising COVID-19 cases as of this time and the results of this study, there is a need for educational authorities and administrators to provide urgent attention to support the teachers and other vulnerable groups who may have mental issues. This paper underscores the importance of assessing the fear of COVID-19 and remote teaching burnout of the teachers so that strategic support mechanisms, especially during the recovery phase of education, may be placed ahead. Moreover, this study brings several significant contributions to the research community. As can be recalled in the review of theories, there are few clearly established links that recognize the association between fear and burnout in different contexts. This current paper, with its encouraging results, provides an empirical piece of evidence on the connection between fear and burnout in the complex context of education. Considering further the current global phenomenon, this article adds to the growing body of scholarly works related to COVID-19 crisis and its psychological impacts. It hopes to provide a better understanding of fear and burnout as induced by the crisis and experienced by the teachers in the field.

This paper may be the first to explore the association between fear of COVID-19 and remote teaching burnout of a large sample of Filipino teachers through an online survey, but some limitations should be observed in interpreting the results. While this study involved a large sample size, most of the respondents came from a single geographical location, thus it is necessary to be cautious when making generalizations to all teachers. It indicates the need to replicate similar studies using stratified samples across different contexts to confirm the

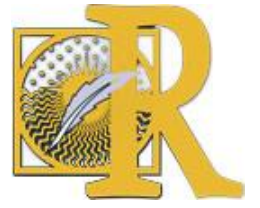

Fecha de recepción: 23-03-2021 Fecha de aceptación: 11-04-2021

Carreon, T., Rotas, E., Cahapay,M., Garcia,K., Amador, R. \& Anoba, J.L. Miedo al COVID-19 y al agotamiento

de la Enseñanza Remota de los Maestros Filipinos de K a 12.

International Journal of Educational Research and Innovation (IJERI), 15, 552-567

ISSN: 2386-4303 DOI https://doi.org/10.46661/ijeri.5853 
results. This study collected the needed data through online procedures. A possible limitation may be reporting bias since this paper depends on self reports of the teachers. This study also uncovered a modest influence of fear of COVID-19 on remote teaching burnout. It did not test other factors that may contribute to the remote teaching burnout of the teachers and how such a burnout may vary, which other researchers may explore in the future.

\section{References}

- Abdelghani, M., El-Gohary, H.M., Fouad, E. \& Hassan, M. S. (2020). Addressing the Relationship Between Perceived Fear of COVID-19 Virus Infection and Emergence of Burnout Symptoms in a Sample of Egyptian Physicians During COVID-19 Pandemic: A Cross-Sectional Study. Middle East Curr Psychiatry 27, 70. https://doi.org/10.1186/s43045$\underline{020-00079-0}$

- Ahorsu, D.K., Lin, C.Y., Imani, V., Saffari, M., Griffiths M. D., Pakpour, A. H., (2020). The fear of COVID-19 scale: Development and initial validation. Int $J$ Ment Health Addiction. https://doi.org/10.1007//s11469-020-00270-8

- Alyami, M., Marcus, H., Krägeloh, C., \& Alyami, H. (2020). Psychometric Evaluation of the Arabic Version of the Fear of COVID-19 Scale. Int $J$ Ment Health Addict. doi: 10.1007/s11469-020-00316-x

- Aperribai, L., Cortabarria, L., Aguirre, T., Verche, E., \& Borges, A. (2020). Teacher's Physical Activity and Mental Health During Lockdown Due to the COVID-2019 Pandemic. Front Psychology. https://doi.org/10.3389/fpsyg.2020.577886

- Arvidsson, I., Leo, U., Larsson, Hakansson, C., Persson R., \& Bjork, J. (2019) Burnout among school teachers: quantitative and qualitative results from a follow-up study in southern Sweden. BMC Public Health. https://doi.org/10.1186/s12889-019-6972-1

- Barello S., Palamenghi L., Graffigna G. (2020, May 27). Burnout and Somatic Symptoms Among Frontline Healthcare Professionals at the Peak of the Italian COVID-19 Pandemic Psychiatry Res. 290:113129. pmid:32485487

- Barling, J. (1996). The prediction, experience, and consequences of workplace violence. In G. R. VandenBos \& E. Q. Bulatao (Eds.), Violence on the job: Identifying risks and developing solutions (p. 29-49). American Psychological Association. https://doi.org/10.1037/10215-001

- Barrios I., Ríos-González C., O’Higgins M., González I., García O., Díaz N. R., et al. (2020). Psychometric properties of the Spanish version of the Fear of COVID-19 Scale (FCV-19S). Int. J. Ment. Heal. Addict, 1-14. doi: 10.21203/RS.3.RS-33345/V1

- Bouckenooghe, D. (2009). Change recipients' attitudes toward change: A review study. Vlerick Leuven Gent Working Paper Series, 14, 201-217. Retrieved from https://public.vlerick.com/Publications/6f43ee88-6aa9-e011-8a89-005056a635ed.pdf

- Cervantes-Guevara, G., Maciel-Saldierna, M., Elizondo-Hernández, E. et al. (2021). Fear of COVID-19 in High School Personnel: A Survey Study in Western Mexico. Int J Ment Health Addiction. https://doi.org/10.1007/s11469-020-00473-z

- Crossman, A. (2020). What is a Snowball Sample in Sociology? ThoughtCo. Retrieved from https://www.thoughtco.com/snowball-sampling-3026730

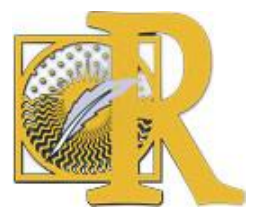

Fecha de recepción: 23-03-2021 Fecha de aceptación: 11-04-2021

Carreon, T., Rotas, E., Cahapay,M., Garcia,K., Amador, R. \& Anoba, J.L. Miedo al COVID-19 y al agotamiento

de la Enseñanza Remota de los Maestros Filipinos de K a 12.

International Journal of Educational Research and Innovation (IJERI), 15, 552-567

ISSN: 2386-4303 DOI https://doi.org/10.46661/ijeri.5853 
- Curtis, E. A., Comiskey, C., Dempsey, O. (2016) Importance and use of correlational research. Nurse Researcher, 23(6), 20-25. doi: 10.7748/nr.2016.el1382

- Daniels (Eds.). A day in the life of a happy worker (pp. 114-131). Hove, Sussex: Psychology Press.

- Delamarter, J. \& Ewart, M. (2020). Responding to Student Teachers' Fears: How We're Adjusting during the COVID-19 Shutdowns. Northwest Journal of Teacher Education, 15 (1), Article 3. https://doi.org/10.15760/nwjte.2020.15.1.3

- Demerouti, E., Bakker, A. B., Nachreiner, F., \& Ebbinghaus, M. (2002). From mental strain to burnout. European Journal of Work and Organizational Psychology, 11(4), 423-441. https://doi.org/10.1080/13594320244000274

- Doshi, D., Karunakar, P., Sukhabogi, J. R., Prasanna, J. S., \& Mahajan, S. V. (2020). Assessing Coronavirus Fear in Indian Population Using the Fear of COVID-19 Scale. International journal of mental health and addiction, 1-9. Advance online publication. https://doi.org/10.1007/s11469-020-00332-x

- Duarte, I., Teixeira, A., Castro, L., Marina, S., Ribeiro, C., Jacome, C., Martins, V., Vaz, I. R., Pinheiro, H. C., Silva, A. R., Ricou, M., Sousa, B., Alves, C., Loiveria, A., Silva, P., Nunes, R., \& Serrao, C. (2020). Burnout among Portuguese healthcare workers during the COVID-19 pandemic. BMC Public Health. https://doi.org/10.1186/s12889-020-09980-z

- Fernández-Batanero, J.-M., Román-Graván, P., Reyes-Rebollo, M.-M., \& MontenegroRueda, M. (2021). Impact of Educational Technology on Teacher Stress and Anxiety: A Literature Review. International Journal of Environmental Research and Public Health, 18(2), 548. MDPI AG. Retrieved from http://dx.doi.org/10.3390/ijerph18020548

- Fisher, M. H. (2011). Factors Influencing Stress, Burnout, and Retention of Secondary Teachers. Current Issues in Education, 14(1). Retrieved from http://cie.asu.edu/

- Fitzpatrick, K., Harris, C., Drawve, G. (2020). Fear of COVID-19 and the Mental Health Consequences in America. American Psychological Association ISSN: 1942-9681. http://dx.doi.org/10.1037/tra0000924

- Flores, M. A., \& Swennen, A. (2020) The COVID-19 Pandemic and its Effects on Teacher Education, European Journal of Teacher Education, 43 (4), 453-456. https://doi.org/10.1080/02619768.2020.1824253

- Fried, A. L., \& Fisher, C. B. (2016). Moral Stress and Job Burnout Among Frontline Staff Conducting Clinical Research on Affective and Anxiety Disorders. Professional psychology, research and practice, 47(3), 171-180. https://doi.org/10.1037/pro0000060

- Gezgin, D., Hamutoglu, N., Gemikonakli, O. \& Raman, I. (2017). Social Networks Users: Fear of Missing Out in Preservice Teachers. Journal of Education and Practise. 18. 156168.

- González-Hernández J, da Silva CM, Monteiro D, Alesi M, Gómez-López M. (2021). Effects of Commitment on Fear of Failure and Burnout in Teen Spanish Handball Players. Frontiers in Psychology. DOI: 10.3389/fpsyg.2021.640044.

- Gross, S., Meier, L. L., \& Semmer, N. K. (2013). Latent growth modeling applied to diary data: The trajectory of vigor across a working week as an illustrative example. In A. B. Bakker, \& K.

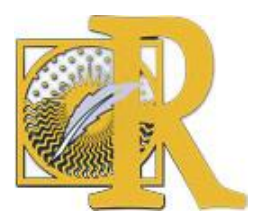

Fecha de recepción: 23-03-2021 Fecha de aceptación: 11-04-2021 
- Giusti, E. M., Pedroli, E., D’Aniello G. E., Badiale, C.S., Pietrabissa, G., Manna, C., Badiale, M. S., Riva, G., Castelnuovo, G., \& Molinari, E. (2020). The Psychological Impact of the COVID-19 Outbreak on Health Professionals: A Cross-Sectional Study Front Psychology. https://doi.org/10.3389/fpsyg.2020.01684

- Gustafsson, H., Sagar, S., \& Stenling, A. (2016). Fear of Failure, Psychological Stress and Burnout Among Adolescent Athletes Competing in High Level Sport. Scandinavian Journal of Medicine and Science in Sports, 27. doi: 10.1111/sms.12797.

- Gross, S., Meier, L. L., \& Semmer, N. K. (2013). Latent growth modeling applied to diary data: The trajectory of vigor across a working week as an illustrative example. In A. B. Bakker \& K. Daniels (Eds.), Current issues in work and organizational psychology. A day in the life of a happy worker (p. 114-131). Psychology Press.

- Haktanir, A., Seki, T. \& Dilmaç, B. (2020). Adaptation and evaluation of Turkish version of the fear of COVID-19 Scale, Death Studies. DOI: 10.1080/07481187.2020.1773026

- Hanson, G. C., Perrin, N. A., Moss, H., Laharnar, N., \& Glass, N. (2015). Workplace violence against homecare workers and its relationship with workers' health outcomes: a crosssectional study. BMC public health, 15, 11. https://doi.org/10.1186/s12889-014-1340-7

- Hayes, S., Priestley, J., Ishmakhametov, N., \& Ray, H., "“I'm not Working from Home, I'm Living at Work": Perceived Stress and Work-Related Burnout before and during COVID-19" (2020). Faculty Publications. 4607. https://digitalcommons.kennesaw.edu/facpubs/4607

- Hidalgo, R. A. J., Pantaleon, Y., Dios, I., \& Falla, D. (2020). Fear of COVID-19, Stress, and Anxiety in University Undergraduate Students: A Predictive Model for Depression. Front Psychology. https://doi.org/10.3389/fpsyg.2020.591797

- Hu, D., Kong, Y., Li, W., Han, Q., Zhang, X., \& Zhu, L.X. (2020). Frontline Nurses' Burnout, Anxiety, Depression, and Fear Statuses and their Associated Factors During the COVID19 Outbreak in Wuhan, China: A Large-Scale Cross-Sectional Study. EClinicalMedicine. https://doi.org/10.1016/j.eclinm.2020.100424

- Huo, L., Zhou, Y., Li, S., Ning, Y., Zeng, L. Liu, Z., Qian, W., Yang, J., Zhou, X., Liu, T., \& Zhang, X. (2020). Burnout and its Relationship with Depressive Symptoms in Medical Staff During the COVID-19 Epidemic in China

- Kraft, M., Simon, N., \& Lyon, M. (2020). Sustaining a Sense of Success: The Importance of Teacher Working Conditions During the COVID-19 Pandemic. EdWorkingPaper, 20-279. Retrieved from Annenberg Institute at Brown University: https://doi.org/10.26300/35nj-v890

- Lazarus, R. S., \& Folkman, S. (1984). Stress, appraisal, and coping. New York: Springer.

- Li, Q., Miao, Y., Zeng, X., Tarimo, C., Wu, C., \& Wu, J. (2020). Prevalence and factors for anxiety during the coronavirus disease 2019 (COVID-19) epidemic among the teachers in China. Journal of Affective Disorder. https://doi.org/10.1016/j.jad.2020.08.017

- Mahmoodi-Shahrebabaki, $\mathrm{M}$. (2019).

Teacher

Burnout. DOI:10.1002/9781118784235.eelt0964.

- Marchetti. A., Di Dio. C., Massaro, D., and Manzi. F., (2020). The Psychosocial Fuzziness of Fear in the Coronavirus (COVID-19) Era and the Role of Robots. Front. Psychol. 11:2245. doi: 10.3389/fpsyg.2020.02245

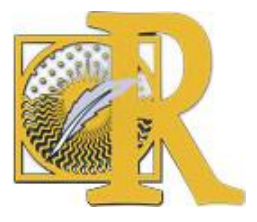

Fecha de recepción: 23-03-2021 Fecha de aceptación: 11-04-2021 
- Mazlach, C., \& Leiter, M. P. (2016). Understanding the burnout experience: recent research and its implications for psychiatry. World psychiatry: Official journal of the World Psychiatric Association (WPA), 15(2), 103-111. https://doi.org/10.1002/wps.20311

- Masuyama, A., Shinkawa, H. \& Kubo, T. (2020) Validation and Psychometric Properties of the Japanese Version of the Fear of COVID-19 Scale Among Adolescents. Int $J$ Ment Health Addiction. https://doi.org/10.1007/s11469-020-00368-z

- Mertens, G., Gerritsen, L. Duijndam, S., Salemink, E., Engelhard, M. (2020). Fear of the Coronavirus (COVID-19): Predictors in an Online Study Conducted. Journal of Anxiety Disorders. https://doi.or/10.1016/j.janxdis.2020.102258

- Moehle K.A., \& Levitt E.E. (1991) The History of the Concepts of Fear and Anxiety. In: Walker C.E. (eds) Clinical Psychology. Applied Clinical Psychology. Springer, Boston, MA. https://doi.org/10.1007/978-1-4757-9715-2 6

- Panisoara, I., Panisoara, G., Lazar, I., Chirca, R., \& Ursu, A. (2020). Motivation and Continuance Intention towards Online Instruction among Teachers during the COVID-19 Pandemic: The Mediating Effect of Burnout and Technostress. Int. J. Environ. Res. Public Health, 17(21), 8002. https://doi.org/10.3390/ijerph17218002

- Pishe, M. M. (2008). A Study of The Relationship Between Fear of Success and Burnout Among Working Women in Iranian Public Schools. Asian Academy of Management Journal. $13(1), 1-14$.

- Portoghese, I., Galletta, M. M. P., Leiter, P. C., D’Aloja, E., \& Campagna, M. (2017). Fear of Future Violence at Work and Job Burnout: A Diary Study on the Role of Psychological Violence and Job Control. Burnout Research, 7, 36-46, ISSN 2213-0586. https://doi.org/10.1016/j.burn.2017.11.003.

- Prikhidko, A., Long, H., \& Wheaton, M. G. (2020). The Effect of Concerns About COVID19 on Anxiety, Stress, Parental Burnout, and Emotion Regulation: The Role of Susceptibility to Digital Emotion Contagion. Frontiers in public health, 8, 567250. https://doi.org/10.3389/fpubh.2020.567250

- Rogers, K.-A., \& Kelloway, E. K. (1997). Violence at work: Personal and organizational outcomes. Journal of Occupational Health Psychology, 2(1), 63-71. https://doi.org/10.1037/1076-8998.2.1.63

- Salloum , S. A., Saeed Al-Maroof, R., Ella Hassanien, A., \& Shaalan, K. (2020): Fear from COVID-19 and technology adoption: the impact of Google Meet during Coronavirus pandemic, Interactive Learning

Environments. https://doi.org/10.1080/10494820.2020.1830121

- Sakib, N., Bhuiyan, A.K.M., Hossain, S., Al Mamun, F. et al. (2020). Psychometric Validation of the Bangla Fear of COVID-19 Scale: Confirmatory Factor Analysis and Rasch Analysis. International Journal of Mental Health and Addiction. DOI: 10.1007/s11469-02000289-x

- Satici, B., Gocet-Tekin, E., Deniz, M. E., \& Satici, S. A. (2020a). Adaptation of the fear of COVID-19 scale: Its association with psychological distress and life satisfaction in Turkey. International Journal of Mental Health Addiction. 10.1007/s11469-020-00294-0.

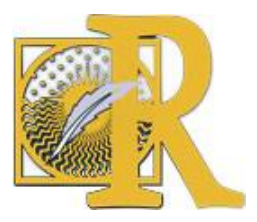

Fecha de recepción: 23-03-2021 Fecha de aceptación: 11-04-2021 
- Son, C., Hegde, S., Smith, A., Wang, X., \& Sasangohar, F. (2020). Effects of COVID-19 on College Students' Mental Health in the United States: Interview Survey Study. Journal of medical Internet research, 22(9), e21279. https://doi.org/10.2196/21279

- Steimer T. (2002). The Biology of Fear- and Anxiety-Related Behaviors. Dialogues in Clinical Neuroscience, 4(3), 231-249. https://doi.org/10.31887/DCNS.2002.4.3/tsteimer

- Sokal, L., Trudel, L.E., \& Babb, J. (2020). Canadian teachers' attitudes toward change, efficacy, and burnout during the COVID-19 pandemic. International Journal of Educational Research Open. https://doi.org/10.1016/j.ijedro.2020.100016

- Soraci, P., Ferrari, A., Abbiah, F., Del Fante, E., De Pace, R., Urso, A., Griffiths, M. (2020) Validation and Psychometric Evaluation of the Italian Version of the Fear of COVID-19 Scale. International Journal of Mental Health and Addiction. https://doi.org/10.1007/s11469-020-00277-1

- Zhang, L., Zhao, J., Xiao, H., Zheng, H., Xiao, Y., Chen, M., \& Chen, D. (2014). Mental Health and Burnout in Primary and Secondary School Teachers in the Remote Mountain Areas of Guangdong Province in the People's Republic of China. Neuropsychiatr Dis Treat., 10, 123-130. doi: 10.2147/NDT.S56020 